\title{
Evaluasi Efektivitas Sistem Pengendalian Internal Proyek Pemerintah di Bawah Pengawasan PT. Pembangunan Perumahan (Persero) Tbk.
}

\author{
Ni Made Win Karoyani ${ }^{1}$ \\ A.A.N.B. Dwirandra ${ }^{2}$ \\ ${ }^{1,2}$ Fakultas Ekonomi dan Bisnis Universitas Udayana (Unud), Bali, Indonesia \\ e-mail: winkaroyani61@gmail.com
}

\begin{abstract}
ABSTRAK
Sampel dalam penelitian ini berjumlah 35 orang dengan metode Non-Probability, khususnya Purposive Sampling (Sampel Pertimbangan). Metode pengumpulan data dilakukan melalui kuesioner (angket), observasi, serta wawancara. Teknik analisis yang digunakan adalah analisis data deskriptif kuantitatif komparatif. Berdasarkan hasil analisis, efektivitas sistem pengendalian internal dan dimensi SPI seluruhnya masuk dalam kategori efektif, namun untuk unsur dari masing-masing dimensi SPI beberapa mendapat hasil penilaian efektif dan sangat efektif. Berdasarkan hasil penilaian skor responden, seluruh skor tersebut belum mencapai nilai maksimum 6, sehingga baik sistem pengendalian internal, dimensi sistem pengendalian internal, maupun unsur dari masing-masing dimensi masih perlu untuk ditingkatkan dan dilakukan perbaikan.
\end{abstract}

Kata kunci: SPI, dimensi, unsur, efektivitas.

\begin{abstract}
The sample in this study was released by 35 people with Non-Probability methods, especially Purposive Sampling (Sample Considerations). The method of data collection is done through questionnaires, observations, and interviews. The analysis technique used is the analysis of comparative quantitative descriptive data. Based on the results of the analysis, the internal control system and the SPI dimension are all included in the effective category, but for each dimension, the SPI of various assessment results is effective and very effective. Based on the results of the respondents' scores, all of these scores have not reached a maximum value of 6 , so that both the internal control system, internal control system dimensions, or from each dimension still need to be improved.

Keywords: SPI, dimensions, elements, effectiveness
\end{abstract}

\section{PENDAHULUAN}

Pesatnya perkembangan dunia bisnis saat ini, menuntut suatu perusahaan untuk secara efektif dan efisien mengelola usahanya agar tercipta suatu keunggulan kompetitif, sehingga diperlukan adanya suatu sistem yang baik di dalam perusahaan. Sistem tersebut haruslah dirancang dengan tepat sehingga mampu mengorganisasikan fungsi-fungsi dan sumber daya yang dimiliki perusahaan serta 
menjadi alat bantu bagi perusahaan dalam mengelola pengendalian aktivitas perusahaan (Ridho \& Andono, 2013).

Perusahaan harus mampu meningkatkan daya saing dengan terus memperbaiki kegiatan operasional perusahaan agar dapat tetap bertahan. Salah satu perbaikan yang dapat dilakukan adalah pada sistem pengendalian internal perusahaan. Sistem pengendalian internal perusahaan harus dievaluasi dari waktu ke waktu sehingga dapat memberikan manajemen beberapa jaminan mengenai efektivitasnya (Tunji, 2013). (Samuel \& Wagoki, 2014) menyebutkan pengendalian internal berlaku bagi setiap organisasi sebagai bagian yang utuh untuk memenuhi tujuan organisasi.

Konsep pengendalian internal sangat penting untuk manajemen organisasi dalam mendeteksi hambatan dan dugaan apabila terdapat kelemahan dalam sistem tersebut, sehingga pendeteksian awal dapat memberikan saran perbaikan bagi sistem pengendalian internal manajemen (Gesare, Michael, \& Odongo, 2016). Aktivitas pengendalian membantu memastikan bahwa tindakan yang diperlukan berkenaan dengan risiko yang diambil untuk pencapaian tujuan organisasi (Jayanti \& Rasmini, 2013).

Pengendalian internal yang baik diperoleh dari suatu struktur yang terkoordinasi, yang berguna bagi pimpinan perusahaan untuk menyusun laporan keuangan dengan lebih teliti, mencegah kecurangan dalam perusahaan, serta mengamankan harta perusahaan (Kumuthinidevi, 2016). Sistem pengendalian internal memiliki dimensi sebagai komponen dari sistem tersebut yang menjadi tolok ukur penting untuk menilai apakah sistem pengendalian internal memang 
telah efektif dilaksanakan di dalam perusahaan (Zamzami \& Faiz, 2015). Dimensi sistem pengendalian internal terdiri dari lima dimensi yaitu lingkungan pengendalian, penilaian risiko, aktivitas pengendalian, informasi dan komunikasi, serta pengawasan (Badara \& Saidin, 2013).

Proyek pembangunan di Indonesia mengalami perkembangan yang cukup baik tahun 2018, hal tersebut diikuti pula dengan meningkatnya pendapatan bagi perusahaan-perusahaan konstruksi di Indonesia.

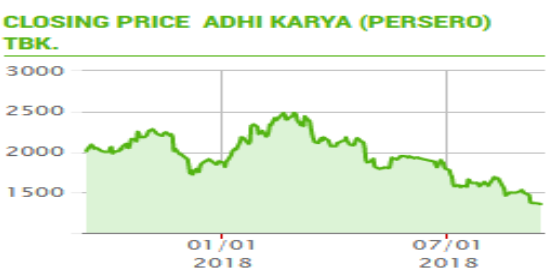

CLOSING PRICE WIJAYA KARYA (PERSERO)

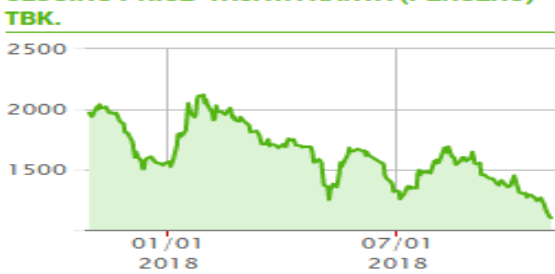

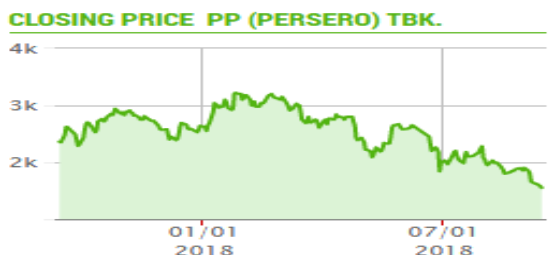
TBK.

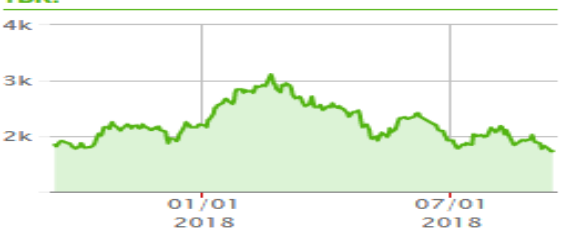

Gambar 1. Gambar Kenaikan Saham BUMN Konstruksi tahun 2018 Sumber: www.bareksa.com, 2018

Gambar tersebut menunjukkan empat saham BUMN konstruksi mulai bangkit dan mencatatkan kenaikan antara 9-15 persen. Kenaikan itu setelah sepanjang tahun lalu, saham-saham tersebut underperfom. Adapun proyeksi kinerja perusahaan konstruksi tahun 2018 disajikan dalam Tabel 1. berikut. 
Tabel 1.

Proyeksi Kinerja Keuangan Emiten BUMN Konstruksi (2018

\begin{tabular}{|c|c|c|c|c|}
\hline Emiten & $\begin{array}{l}\text { Target } \\
\text { Pendapatan (Rp } \\
\text { Miliar) }\end{array}$ & $\begin{array}{l}\text { Target Laba } \\
\text { Bersih } \\
\text { (Rp Miliar) }\end{array}$ & $\begin{array}{l}\text { Target } \\
\text { Kontrak (Rp } \\
\text { Miliar) }\end{array}$ & $\begin{array}{l}\text { Belanja } \\
\text { Modal } \\
\text { (Rp } \\
\text { Miliar) }\end{array}$ \\
\hline $\begin{array}{l}\text { PT Adhi Karya Tbk } \\
\text { (ADHI) }\end{array}$ & 18.000 & 632 & 23.750 & 10.000 \\
\hline PT PP Tbk (PTPP) & 28.500 & 2.100 & 49.100 & 20.000 \\
\hline $\begin{array}{l}\text { PT Waskita Karya Tbk } \\
\text { (WSKT) }\end{array}$ & 55.000 & 5.300 & 72.600 & 20.000 \\
\hline $\begin{array}{l}\text { PT Wijaya Karya Tbk } \\
\text { (WIKA) }\end{array}$ & 30.840 & 1.450 & 51.900 & - \\
\hline
\end{tabular}

Diantara daftar BUMN konstruksi pada tabel 1. tersebut salah satunya yaitu PT. Pembangunan Perumahan (Persero) Tbk. Dimana perusahaan saat ini terbagi menjadi beberapa divisi untuk lebih mengefektifkan pekerjaan proyek dan pelayanannya, yaitu: Divisi I (Gedung I, yang menangani proyek swasta dan asing), Divisi (Gedung II, yang menangani proyek pemerintah dan BUMN), Divisi III (Infrastruktur I, yang menangangi SDM proyek), Divisi IV (Infrastruktur II, yang menangani pembangunan non jalan dan jembatan).

\section{METODE PENELITIAN}

Perkembangan proyek pembangunan di Indonesia tahun 2018 khususnya proyek dari Pemerintah cenderung mengarah ke sisi negatif terkait kinerja manajemen proyeknya, yakni banyaknya kegagalan proyek konstruksi dalam pembangunan yang diduga karena kegagalan manajemen internal perusahaan yang menangani proyek Pemerintah tersebut. Perusahaan konstruksi besar seperti PT. Hutama Karya, Adhi Karya, Wijaya Karya, serta Waskita Karya tahun 2018 ini telah tercatat mengalami kegagalan dalam proyek konstruksi Pemerintah yang mereka kerjakan (www.bbc.com, 5 Februari 2018). 
Kasus yang juga dialami perusahaan konstruksi di Indonesia tahun ini selain kasus kegagalan dalam proyek yaitu tindakan korupsi yang dilakukan oleh PT. Nindya Karya, dimana perusahaan konstruksi tersebut merupakan perusahaan BUMN pertama yang menjadi tersangka kasus korupsi yang melibatkan personel internal perusahaan (www.detik.com, 13 April 2018).

Kasus-kasus di atas menunjukkan adanya indikasi sistem pengendalian internal perusahaan yang lemah khususnya terkait pengawasan dari manajamen internal perusahaan untuk proyek-proyek yang mereka tangani. Pengawas proyek internal perusahaan memiliki peranan yang penting dan krusial bagi keberlangsungan proyek tersebut. Pengawas tersebut meminimalkan kesalahan yang mengakibatkan pembongkaran dan pengulangan pekerjaan yang tidak perlu karena kesalahan gambar ataupun mutu pekerjaan yang tidak memenuhi ketentuan, selain itu mereka melakukan koordinasi dan pengendalian seluruh kegiatan teknis pembangunan dari tahap pelaksanaan konstruksi dan masa pemeliharaan, baik yang menyangkut aspek manajemen maupun teknologi (Simanjuntak \& Djukardi, 2013). Selama menjalankan tugasnya sebagai pengawas, dibutuhkan sikap independensi agar tidak terjadi ketimpangan pengawasan yang nantinya mengarah kepada kegagalan dari proyek tersebut. Independensi tersebut merupakan sikap dimana pengawas bekerja secara profesional tanpa benturan kepentingan dan pengaruh atau tekanan dari pihak manapun, baik dari internal maupun eksternal perusahaan (Rivelino \& Soekiman, 2016). 
Ni Made Win Karoyani dan A.A.N.B. Dwirandra. Evaluasi ...

Kasus-kasus perusahaan konstruksi di atas menjadi alasan dipilihnya PT. Pembangunan Perumahan (Persero) Tbk. Divisi Gedung II sebagai lokasi penelitian, karena tahun ini citra perusahaan sedang baik tanpa adanya isu kasuskasus tersebut, dimana Divisi Gedung II PT. Pembangunan Perumahan (Persero) Tbk. merupakan divisi khusus yang menangangi pekerjaan seluruh proyek dari Pemerintah. Berdasarkan pemaparan latar belakang di atas, maka penulis tertarik untuk melakukan penelitian mengenai efektivitas sistem pengendalian internal dengan judul "Evaluasi Efektivitas Sistem Pengendalian Internal Proyek Pemerintah di Bawah Pengawasan PT. Pembangunan Perumahan (Persero) Tbk. Divisi Gedung II".

Sistem pengendalian internal perusahaan harus dievaluasi dari waktu ke waktu sehingga dapat memberikan manajemen beberapa jaminan mengenai efektivitasnya (Lameng \& Dwirandra, 2018). Sistem pengendalian internal memiliki dimensi yang menjadi tolok ukur penting untuk menilai apakah sistem pengendalian internal tersebut memang telah efektif dilaksanakan di dalam perusahaan (Mahendra \& Ramantha, 2018).

Penelitian ini dilakukan pada salah satu perusahaan BUMN Indonesia yang bergerak di bidang perencanaan dan konstruksi bangunan (real estate) yaitu PT. Pembangunan Perumahan (Persero) Tbk. Divisi Gedung II yang beralamat di PLAZA PP Lantai 6, Jalan TB. Simatupang No. 57, Pasar Rebo, Jakarta Timur 13760. 
Populasi dalam penelitian ini adalah seluruh karyawan PT. Pembangunan Perumahan (Persero) Tbk. Divisi Gedung II yang berjumlah 82 karyawan tetap dan 43 karyawan kontrak.

Metode penentuan sampel dalam penelitian ini menggunakan teknik sampling Non-Probability, yaitu teknik pengambilan sampel yang tidak dipilih secara acak, dengan metode Purposive Sampling (Sampel Pertimbangan), yaitu teknik sampling yang dipilih berdasarkan pertimbangan tertentu dengan tujuan untuk memperoleh satuan sampling yang memiliki karakteristik yang dikehendaki oleh peneliti. Kriteria sampel yang digunakan dalam penelitian ini adalah pengawas internal, senior manajer, general manajer, serta asisten manajer yang terlibat dalam proses pengendalian internal terkait proyek-proyek Pemerintah di Divisi Gedung II. Kriteria ini dipilih karena personel tersebut yang paling mengetahui dan memahami bagaimana penilaian kinerja dari proyek-proyek Pemerintah tersebut, serta pemilihan secara generalisasi dari struktur organisasi merupakan salah satu ciri sistem pengendalian internal yang efektif. Sampel dalam penelitian ini berjumlah 35 orang, yang terdiri dari 2 pengawas proyek internal perusahaan yang sekaligus sebagai general manajer opersional, 4 senior manajer, serta 29 asisten manajer dan anggotanya yang mewakili seluruh bagian manajemen.

Teknik analisis data yang digunakan dalam penelitian ini adalah teknik analisis data deskriptif kuantitatif komparatif, yaitu teknik analisis data berupa perhitungan serta membandingkan hasil penelitian dengan standar SPI yang ditetapkan oleh BPKP dari respon responden terhadap efektivitas penerapan 
sistem pengendalian internal, dimensi SPI, maupun unsur dari masing-masing dimensi.

\section{HASIL DAN PEMBAHASAN}

Dari 35 kuesioner yang digunakan dalam penelitian, diperoleh gambaran mengenai karakteristik responden berdasarkan pendidikan dan jenis kelamin yang disajikan dalam Tabel 2 berikut.

Tabel 2.

Karakteristik Responden

\begin{tabular}{llllr}
\hline No. & Karakteristik & & Jumlah & Persentase \\
\hline 1. & Jenis Kelamin & Responden & $82,86 \%$ \\
& & Wanita & 6 & $17,14 \%$ \\
2. & \multirow{3}{*}{ Tingkat Pendidikan } & Total & 35 & $100 \%$ \\
& & S3 & 6 & $17,14 \%$ \\
& & 8 & $22,86 \%$ \\
& & S2 & 21 & $60 \%$ \\
3. & Latar Belakang Pendidikan & Total & 35 & $100 \%$ \\
& & Teknik & 8 & $22,86 \%$ \\
& Akuntansi & 9 & $25,71 \%$ \\
& Manajemen & 10 & $28,57 \%$ \\
& & Ekonomi & 3 & $8,57 \%$ \\
& & Lainnya & 5 & $14,29 \%$ \\
& & Total & 35 & $100 \%$ \\
\hline Sumber: Data diolah, 2018 & & &
\end{tabular}

Dari Tabel 2 diketahui bahwa jumlah responden pria berjumlah 82, 86\% lebih banyak dibanding responden wanita, dan latar belakang pendidikan teknik merupakan jumlah terbanyak dari responden sebesar $22,86 \%$. Tingkat pendidikan responden sudah pada tingkat S3 untuk teknik dan manajemen, dan tingkat pendidikan yang terendah yaitu tingkat S1 dari akuntansi. Hal ini menunjukkan bahwa tingkat pendidikan merupakan hal yang penting dalam perusahaan, oleh karena itu PT. Pembangunan Perumahan (Persero) terus memastikan dan 
berupaya untuk meningkatkan kualitas pengelolaan Sumber Daya Manusia (SDM) yang profesional.

Efektivitas sistem pengendalian internal, dimensi SPI, dan unsur dari masing-masing dimensi dapat ditentukan dengan melihat skor respon dari responden terkait sistem pengendalian internal, dimensi SPI, serta unsur dari masing-masing dimensi.

Efektivitas sistem pengendalian internal didapat melalui perhitungan ratarata statistik dari masing-masing dimensi sistem pengendalian internal proyek Pemerintah di bawah pengawasan PT. Pembangunan Perumahan (Persero) Tbk. Divisi Gedung II. Tabel 3 memperlihatkan hasil statistik deskriptif sistem pengendalian internal sebagai berikut:

Tabel 3.

Efektivitas Sistem Pengendalian Internal (SPI) dan Dimensi SPI

\begin{tabular}{|c|c|c|c|c|c|}
\hline SPI/Dimensi & $\mathrm{N}$ & Minimum & Maximum & Mean & Keterangan \\
\hline Dimensi: & 35 & 3,89 & 5,91 & 4,89 & Efektif \\
\hline $\begin{array}{l}\text { 1) Lingkungan } \\
\text { Pengendalian }\end{array}$ & 35 & 4,00 & 5,76 & 4,97 & Kondusif \\
\hline $\begin{array}{l}\text { 2) Penilaian } \\
\text { Risiko }\end{array}$ & 35 & 3,80 & 6,00 & 4,82 & Tidak Berisiko \\
\hline $\begin{array}{l}\text { 3) Aktivitas } \\
\text { Pengendalian }\end{array}$ & 35 & 4,00 & 5,79 & 4,94 & Efektif \\
\hline $\begin{array}{l}\text { 4) Informasi } \\
\text { dan } \\
\text { Komunikasi }\end{array}$ & 35 & 4,00 & 6,00 & 4,92 & $\begin{array}{l}\text { Informatif dan } \\
\text { Komunikatif }\end{array}$ \\
\hline 5) Pengawasan & 35 & 3,67 & 6,00 & 4,81 & Efektif \\
\hline Total & 35 & 19,47 & 29,55 & 24,46 & \\
\hline
\end{tabular}

Berdasarkan tabel rata-rata efektivitas sistem pengendalian internal (SPI) dan dimensi SPI di atas, sistem pengendalian internal proyek Pemerintah yang dikerjakan di bawah pengawasan PT. Pembangunan Perumahan (Persero) Tbk. Divisi Gedung II mendapat hasil perhitungan 4,89. Dengan rata-rata 4,89 tersebut, 
Ni Made Win Karoyani dan A.A.N.B. Dwirandra. Evaluasi ...

sesuai dengan kriteria yang ditetapkan oleh BPKP, maka masuk dalam kategori efektif.

Hasil perhitungan ini menunjukkan bahwa pelaksanaan sistem pengendalian internal dalam pengerjaan proyek Pemerintah di bawah pengawasan PT. Pembangunan Perumahan (Persero) Tbk. Divisi Gedung II sudah berjalan efektif khususnya terkait pengawasan dari manajamen internal perusahaan untuk proyek pemerintah yang mereka tangani. Masing-masing dimensi sistem pengendalian internal telah berjalan dengan efektif pula dimana dimensi aktivitas pengendalian merupakan rata-rata perhitungan dengan hasil tertinggi dibanding dimensi lainnya, sedangkan dimensi pengawasan merupakan nilai yang terendah. Meskipun telah masuk dalam kategori efektif, namun perlu untuk dilakukan perbaikan terutama pada dimensi pengawasan sebagai skor rata-rata terendah. Dalam rangka mengetahui perbaikan dari sistem pengendalian internal perlu ditelusuri efektivitas dari masing-masing dimensi sistem pengendalian internal.

Efektivitas dimensi sistem pengendalian internal dapat dilihat dari rata-rata skor jawaban responden terhadap masing-masing dimensi sistem pengendalian internal proyek Pemerintah di bawah pengawasan PT. Pembangunan Perumahan (Persero) Tbk. Divisi Gedung II yang merujuk kembali pada Tabel 3 di atas.

Berdasarkan tabel rata-rata efektivitas sistem pengendalian internal (SPI) dan dimensi SPI di atas, dimensi lingkungan pengendalian mendapat hasil 
perhitungan 4,97. Dengan hasil rata-rata 4,97 tersebut, sesuai dengan kriteria yang ditetapkan oleh BPKP, maka masuk dalam kategori efektif. Dimensi penilaian risiko mendapat hasil perhitungan 4,82. Dengan hasil rata-rata 4,82 tersebut, sesuai dengan kriteria yang ditetapkan oleh BPKP, maka masuk dalam kategori efektif pula. Dimensi aktivitas pengendalian mendapat hasil perhitungan 4,94. Dengan hasil rata-rata 4,94 tersebut, sesuai dengan kriteria yang ditetapkan oleh BPKP, maka masuk dalam kategori efektif. Untuk dimensi informasi dan komunikasi mendapat hasil perhitungan 4,92. Dengan hasil rata-rata 4,92 tersebut, sesuai dengan kriteria yang ditetapkan oleh BPKP, maka masuk dalam kategori yang telah efektif. Terakhir, untuk dimensi pengawasan mendapat hasil perhitungan 4,81. Dengan hasil rata-rata 4,81 tersebut, sesuai dengan kriteria yang ditetapkan oleh BPKP, maka masuk dalam kategori efektif.

Dari seluruh hasil penilaian efektivitas tersebut, tidak ada satupun dari dimensi sistem pengendalian internal proyek Pemerintah yang dikerjakan di bawah pengawasan PT. Pembangunan Perumahan (Persero) Tbk. Divisi Gedung II mendapat skor penilaian maksimum 6, sehingga seluruh dimensi perlu untuk dilakukan perbaikan. Dalam rangka mengetahui perbaikan dari masing-masing dimensi, maka perlu ditelusuri unsur dari masing-masing dimensi sistem pengendalian internal tersebut.

Efektivitas unsur masing-masing dimensi dapat dilihat dari skor respon responden unsur per dimensi. 
Tabel 5.

Gambaran Hasil Skor Unsur Dimensi Lingkungan Pengendalian

\begin{tabular}{|c|c|c|c|}
\hline \multirow{2}{*}{\multicolumn{2}{|c|}{$\begin{array}{l}\text { Unsur } \\
\text { Integritas dan Nilai Etika }\end{array}$}} & Rata-rata Jawaban & Keterangan \\
\hline & & & \\
\hline \multicolumn{2}{|c|}{ Rata-rata nilai per unsur } & 4,97 & Kondusif \\
\hline a) & Penerapan aturan perilaku & 4,97 & Kondusif \\
\hline b) & Tindakan disiplin & 5,14 & Sangat Kondusif \\
\hline c) & Intervensi SPI & 4,80 & Kondusif \\
\hline \multicolumn{4}{|c|}{ Komitmen } \\
\hline \multicolumn{2}{|c|}{ Rata-rata nilai per unsur } & 5,03 & Sangat Kondusif \\
\hline a) & Identifikasi tugas dan fungsi & 4,97 & Kondusif \\
\hline b) & Diklat pekerja & 5,09 & Sangat Kondusif \\
\hline \multicolumn{4}{|c|}{ Kepemimpinan } \\
\hline \multicolumn{2}{|c|}{ Rata-rata nilai per unsur } & 5,02 & Sangat Kondusif \\
\hline a) & Pertimbangan risiko & 5,10 & Sangat Kondusif \\
\hline b) & $\begin{array}{l}\text { Penerapan manajemen } \\
\text { kinerja }\end{array}$ & 5,00 & Sangat Kondusif \\
\hline c) & Penerapan fungsi SPI & 4,74 & Kondusif \\
\hline d) & Perlindungan aset & 4,90 & Kondusif \\
\hline e) & Interaksi intensif pimpinan & 5,06 & Sangat Kondusif \\
\hline f) & $\begin{array}{l}\text { Respon positif tiap } \\
\text { pelaporan }\end{array}$ & 5,30 & Sangat Kondusif \\
\hline \multicolumn{4}{|c|}{ Struktur Organisasi } \\
\hline \multicolumn{2}{|c|}{ Rata-rata nilai per unsur } & 4,32 & Kondusif \\
\hline a) & $\begin{array}{l}\text { Penyesuaian ukuran \& sifat } \\
\text { proyek }\end{array}$ & 4,89 & Kondusif \\
\hline b) & Kejelasan wewenang & 4,97 & Kondusif \\
\hline c) & Kejelasan jenjang pelaporan & 5,10 & Sangat Kondusif \\
\hline d) & Evaluasi stuktur organisasi & 4,80 & Kondusif \\
\hline e) & Penetapan jumlah pekerja & 4,83 & Kondusif \\
\hline f) & $\begin{array}{l}\text { Wewenang pekerja pada } \\
\text { tingkatnya }\end{array}$ & 5,09 & Sangat Kondusif \\
\hline g) & Posisi SPI pekerja & 4,90 & Kondusif \\
\hline \multicolumn{4}{|c|}{ Kebijakan SDM } \\
\hline \multicolumn{2}{|c|}{ Rata-rata nilai per unsur } & 4,85 & Kondusif \\
\hline a) & $\begin{array}{l}\text { Kebijakan rekruitmen } \\
\text { pekerja }\end{array}$ & 4,80 & Kondusif \\
\hline b) & $\begin{array}{l}\text { Penelusuran latar belakang } \\
\text { pekerja }\end{array}$ & 4,86 & Kondusif \\
\hline c) & Supervisi periodik pekerja & 4,90 & Kondusif \\
\hline \multicolumn{4}{|c|}{ Aparat Pengawasan yang Efektif } \\
\hline \multicolumn{2}{|c|}{ Rata-rata nilai per unsur } & 5,03 & Sangat Kondusif \\
\hline a) & $\begin{array}{l}\text { Keyakinan ketaatan dan } \\
\text { efisiensi }\end{array}$ & 5,00 & Sangat Kondusif \\
\hline b) & $\begin{array}{l}\text { Peringatan dini manajemen } \\
\text { risiko }\end{array}$ & 5,14 & Sangat Kondusif \\
\hline c) & Kualitas tata kelola & 4,49 & Kondusif \\
\hline \multicolumn{4}{|c|}{ Hubungan Kerja Departemen Terkait } \\
\hline a) & $\begin{array}{l}\text { Mekanisme saling uji } \\
\text { departemen }\end{array}$ & 4,97 & Kondusif \\
\hline
\end{tabular}

Sumber: Data diolah, 2018 
Berdasarkan tabel hasil skor penilaian unsur dimensi lingkungan pengendalian di atas, dapat dilihat bahwa unsur yang paling rendah nilainya yaitu unsur struktur organisasi sebesar 4,32 sedangkan nilai tertinggi yaitu pada unsur komitmen dan aparat pengawasan yang efektif sebesar 5,03. Seluruh skor unsur dimensi lingkungan pengendalian mendapat nilai di bawah nilai maksimum 6 , sehingga seluruh unsur perlu mendapat perbaikan terutama dari unsur struktur organisasi sebagai skor penilaian terendah.

Unsur aparat pengawasan yang efektif diwujudkan dengan manajer operasional Divisi Gedung II yang sekaligus menjadi pengawas internal proyek pemerintah di divisi tersebut seperti struktur organisasi pada Gambar 4.1, sehingga seluruh proyek dapat diawasi secara intensif. Berdasarkan hasil evaluasi pada unsur-unsur dalam dimensi lingkungan pengendalian, maka pernyataanpernyataan per unsur dengan hasil terendah dapat diberikan solusi seperti yang disajikan pada Tabel 4.6 berikut. 
Tabel 6.

Solusi untuk Efektivitas Unsur Dimensi Lingkungan Pengendalian

\begin{tabular}{|c|c|c|c|c|}
\hline No. & Unsur & Pernyataan & Skor & Solusi \\
\hline 1. & $\begin{array}{l}\text { Integritas dan } \\
\text { Nilai Etika }\end{array}$ & $\begin{array}{l}\text { (Pernyataan 3) } \\
\text { Menjelaskan dan } \\
\text { mempertanggungjawabkan } \\
\text { adanya intervensi atau } \\
\text { pengabaian terkait } \\
\text { pengendalian internal. }\end{array}$ & 4,80 & $\begin{array}{l}\text { Meningkatkan sosialisasi masalah } \\
\text { integritas dan nilai etika serta } \\
\text { peningkatan tanggung jawab } \\
\text { pimpinan terhadap individu dalam } \\
\text { lingkungan pekerjaan. }\end{array}$ \\
\hline 2. & Komitmen & $\begin{array}{l}\text { (Pernyataan 4) } \\
\text { Mengidentifikasi dan } \\
\text { menetapkan kegiatan yang } \\
\text { dibutuhkan untuk } \\
\text { menyelesaikan tugas dan } \\
\text { fungsi pada masing- } \\
\text { masing posisi. }\end{array}$ & 4,97 & $\begin{array}{l}\text { Pimpinan wajib menganalisis } \\
\text { kemampuan setiap individu } \\
\text { sehingga dapat mengidentifikasi } \\
\text { dan mendefinisikan tugas yang } \\
\text { dibutuhkan dalam mengisi } \\
\text { berbagai posisi. }\end{array}$ \\
\hline 3. & Kepemimpinan & $\begin{array}{l}\text { (Pernyataan 8) } \\
\text { Mendukung fungsi tertentu } \\
\text { dalam penerapan SPI. }\end{array}$ & 4,74 & $\begin{array}{l}\text { Peningkatan dukungan pimpinan } \\
\text { terkait dengan fungsi pencatatan } \\
\text { dan pelaporan keuangan, sistem } \\
\text { manajemen } \\
\text { pengelolaaan pegawai, dan } \\
\text { pengawasan baik intern maupun } \\
\text { ekstern. }\end{array}$ \\
\hline 4. & $\begin{array}{l}\text { Struktur } \\
\text { Organisasi }\end{array}$ & $\begin{array}{lr}\text { (Pernyataan 15) } & \\
\text { Melaksanakan } & \text { evaluasi } \\
\text { dan penyesuaian } & \text { periodik } \\
\text { terhadap } & \text { struktur } \\
\text { organisasi } & \text { sehubungan } \\
\text { dengan } & \text { perubahan } \\
\text { lingkungan } & \text { proyek } \\
\text { perusahaan. } & \end{array}$ & 4,80 & $\begin{array}{l}\text { Pimpinan meningkatkan intensitas } \\
\text { pertemuan dengan para pekerja } \\
\text { untuk mengevaluasi perubahan } \\
\text { lingkungan secara rutin terkait } \\
\text { penyesuaiannya dengan struktur } \\
\text { organisasi. }\end{array}$ \\
\hline 6. & $\begin{array}{l}\text { Aparat } \\
\text { Pengawasan } \\
\text { yang Efektif }\end{array}$ & $\begin{array}{l}\text { (Pernyataan 24) } \\
\text { Memelihara dan } \\
\text { meningkatkan kualitas tata } \\
\text { kelola penyelenggaraan } \\
\text { tugas dan fungsi. }\end{array}$ & 4,94 & $\begin{array}{l}\text { Terdapat mekanisme yang } \\
\text { memadai terhadap upaya } \\
\text { peningkatan dan pemeliharaan tata } \\
\text { kelola oleh Aparat Pengawas } \\
\text { Internal. }\end{array}$ \\
\hline 7. & $\begin{array}{l}\text { Hubungan } \\
\text { Kerja } \\
\text { Departemen } \\
\text { Terkait }\end{array}$ & $\begin{array}{l}\text { (Pernyataan 25) } \\
\text { Menjalankan mekanisme } \\
\text { saling uji antar departemen } \\
\text { terkait. }\end{array}$ & 4,97 & $\begin{array}{l}\text { Meningkatkan kegiatan } \\
\text { pembandingan data antar dua atau } \\
\text { lebih departemen yang saling } \\
\text { terkait untuk mendapatkan data } \\
\text { yang akurat. }\end{array}$ \\
\hline
\end{tabular}

Sumber: Pedoman Penyelenggaraan SPIP BPKP, 2009

Dalam rangka mengetahui perbaikan dari unsur dimensi penilaian risiko, maka perlu ditelusuri dari masing-masing pernyataan per unsur seperti yang disajikan pada Tabel 7 berikut. 
Tabel 7.

Gambaran Hasil Skor Unsur Dimensi Penilaian Risiko

\begin{tabular}{ccc}
\hline Unsur & Rata-rata Jawaban & Keterangan \\
\hline Identifikasi Risiko & & \\
Rata-rata nilai per unsur & 4,74 & Tidak Berisiko \\
a) Metodologi komprehensif proyek & 4,69 & Tidak Berisiko \\
b) Mekanisme pengenalan risiko & 4,86 & Tidak Berisiko \\
c) Penilaian faktor lain risiko & 4,68 & Tidak Berisiko \\
Analisis Risiko & & \\
Rata-rata nilai per unsur & 4,92 & Tidak Berisiko \\
a) Penetuan dampak identifikasi risiko & 4,86 & Tidak Berisiko \\
b) Prinsip kehati-hatian pada risiko & 4,97 & Tidak Berisiko
\end{tabular}

Sumber: Data diolah, 2018

Berdasarkan tabel hasil skor penilaian unsur dimensi penilaian risiko di atas, kedua unsur mendapat skor penilaian di bawah nilai maksimum 6 , sehingga kedua unsur perlu mendapat perbaikan terutama dari unsur identifikasi risiko sebagai skor penilaian terendah. Berdasarkan hasil wawancara dan observasi di lokasi penelitian, unsur identifikasi dan analisis risiko dalam pengerjaan proyek pemerintah perusahaan dilakukan berdasarkan pada tujuan dan rencana strategis serta didukung dengan sumber daya perusahaan yang cukup dengan melibatkan seluruh tingkat jabatan yang berkaitan langsung dengan proyek dalam proses penetapan hasil identifikasi dan analisis risiko.

Dimensi penilaian risiko dalam pengerjaan proyek pemerintah di bawah pengawasan PT. Pembangunan Perumahan (Persero) Tbk. Divisi Gedung II juga diwujudkan perusahaan dengan menetapkan kebijakan di bidang Kualitas/Mutu, Keselamatan \& Kesehatan Kerja (K3) dan Lingkungan yang berlaku bagi seluruh unit di Perseroan sebagai tindak antisipasi selama proses pengerjaan proyekproyek perusahaan. Berdasarkan hasil evaluasi pada unsur-unsur dalam dimensi penilaian risiko, maka pernyataan-pernyataan per unsur dengan hasil terendah dapat diberikan solusi seperti yang disajikan pada Tabel 8 berikut. 
Tabel 8.

Solusi untuk Hasil Efektivitas Unsur Dimensi Penilaian Risiko

\begin{tabular}{|c|c|c|c|c|}
\hline No & Unsur & Pernyataan & Skor & Solusi \\
\hline 1. & $\begin{array}{l}\text { Identifikasi } \\
\text { Risiko }\end{array}$ & $\begin{array}{l}\text { (Pernyataan 3) } \\
\text { Menilai faktor lain yang } \\
\text { dapat meningkatkan risiko } \\
\text { kegagalan pembangunan } \\
\text { proyek. }\end{array}$ & 4,68 & $\begin{array}{l}\text { Melakukan pertimbangan } \\
\text { terhadap risiko yang } \\
\text { berhubungan dengan kegalalan } \\
\text { visi dan misi, tujuan masa lalu, } \\
\text { keterbatasan penganggaran, } \\
\text { dan risiko yang melekat pada } \\
\text { misi Pemerintah. }\end{array}$ \\
\hline 2. & $\begin{array}{l}\text { Analisis } \\
\text { Risiko }\end{array}$ & $\begin{array}{l}\text { (Pernyataan 4) } \\
\text { Menentukan dampak dari } \\
\text { risiko yang telah } \\
\text { diidentifikasi terhadap } \\
\text { pencapaian tujuan proyek. }\end{array}$ & 4,86 & $\begin{array}{l}\text { Pimpinan wajib menerapkan } \\
\text { prinsip kehati-hatian dalam } \\
\text { menentukan tingkat risiko yang } \\
\text { dapat diterima. }\end{array}$ \\
\hline
\end{tabular}

Dalam rangka mengetahui perbaikan dari unsur dimensi aktivitas

pengendalian, maka perlu ditelusuri dari masing-masing pernyataan per unsur seperti yang disajikan pada Tabel 9 berikut.

Tabel 9.

Gambaran Hasil Skor Unsur Dimensi Aktivitas Pengendalian

\begin{tabular}{lll}
\hline Unsur & Rata-rata Jawaban & Keterangan \\
\hline $\begin{array}{l}\text { Review Kinerja Departemen } \\
\text { a) Pembandingan kinerja }\end{array}$ & 4,94 & Efektif \\
Pembinaan SDM & & \\
Rata-rata nilai per unsur & 4,89 & Efektif \\
a) Komunikasi visi misi pada pekerja & 5,00 & Sangat Efektif \\
b) Strategi pembinaan SDM & 4,70 & Efektif \\
c) Pembuatan rencana karir pekerja & 4,77 & Efektif \\
Pengendalian Pengelolaan Sistem Informasi & & \\
Rata-rata nilai per unsur & 4,95 & Efektif \\
a) Pengendalian umum sistem informasi & 5,00 & Sangat Efektif \\
b) Pengendalian aplikasi sistem & 4,89 & Efektif \\
Pengendalian Fisik Aset & & \\
Rata-rata nilai per unsur & 4,93 & Efektif \\
a) Komunikasi prosedur pada pekerja $\quad$ Sangat Efektif \\
b) Komunikasi pemulihan bencana & 5,03 & Efektif \\
Review Indikator dan Ukuran Kinerja & 4,83 & \\
Rata-rata nilai per unsur & & Sangat Efektif \\
a) Penetapanindikator kinerja proyek & 5,04 & Sangat Efektif \\
b) Evaluasi periodik kinerja proyek & 5,03 & Sangat Efektif \\
c) Evaluasi faktor penilaian kinerja & 5,03 & Sangat Efektif \\
d) Analisis selisih kinerja proyek & 5,08 & Sangat Efektif \\
Pemisahan Fungsi & 5,00 & Efektif \\
a) Transaksi tidak dipegang 1 pekerja & & \\
Otorisasi Transaksi Penting & 4,68 & Efektif \\
a) Komunikasi otorisasi pada pekerja & 4,80 &
\end{tabular}

Pencatatan yang Akurat dan Tepat Waktu atas Transaksi 
ISSN: 2302-8556

E-Jurnal Akuntansi Universitas Udayana

Vol.27.1.April (2019): 258-284

Rata-rata nilai per unsur

a) Pencatatan segera terkait transaksi

5,06

Sangat Efektif

b) Klasifikasi transaks

5,05

Sangat Efektif

Pembatasan Akses Sumber Daya dan Pencatatannya

a) Akses review pada pekerja berwenang

5,06

Sangat Efektif

Akuntabilitas Sumber Daya dan Pencatatannya

a) Penugasan pegawai khusus

4,94

Efektif

Dokumentasi SPI

a) Pemuktahiran SPI transaksi

Sangat Efektif

Sumber: Data diolah, 2018

Berdasarkan tabel hasil skor penilaian unsur dimensi aktivitas pengendalian

di atas, dapat dilihat bahwa unsur yang paling rendah nilai rata-ratanya yaitu unsur pemisahan fungsi sebesar 4,68 sedangkan nilai tertinggi yaitu pada unsur akuntabilitas sumber daya dan pencatatannya sebesar 5,06. Seluruh skor unsur dimensi aktivitas pengendalian mendapat nilai di bawah nilai maksimum 6, sehingga seluruh unsur perlu mendapat perbaikan terutama dari unsur pemisahan fungsi sebagai skor terendah. Berdasarkan hasil wawancara dan observasi di lokasi penelitian, dimensi aktivitas pengendalian dilakukan dengan review atau membandingkan kinerja proyek. Untuk unsur pembinaan SDM hampir sama penyelenggaraannya seperti pada dimensi lingkungan pengendalian dimana perusahaan telah mempunyai standar baku terkait proses karir karyawan, hal tersebut merupakan hal yang penting mengingat bahwa perusahaan menganggap sumber daya manusia merupakan komponen penting dalam perusahaan.

Unsur pengendalian sistem informasi lebih ditekankan prosesnya dalam proses kerja di gedung divisi berupa pengendalian akses, pemisahan tugas, pengendalian kegiatan pegawai melalui review, otorisasi, serta penggunaan perangkat lunak atau aplikasi yang mutakhir. Unsur pengendalian fisik aset dilakukan lebih mendalam pada saat pengerjaan proyek di lapangan karena menggunakan banyak alat-alat yang beberapa masih bersifat barang leasing. 
Unsur pemisahan fungsi, otorisasi atas transaksi dan kejadian yang penting, serta pembatasan akses atas sumber daya dan pencatatannya dilakukan sama seperti pada unsur pengendalian sistem informasi, namun pada ketiga unsur ini dilakukan khusus pada proses kerja yang berhubungan dengan transaksi. Selain itu pula ada unsur pencatatan yang akurat dan tepat waktu atas transaksi dan kejadian, akuntabilitas terhadap sumber daya dan pencatatannya, dan dokumentasi yang baik atas sistem pengendalian internal serta transaksi dan kejadian penting yang juga berhubungan dengan proses transaksi. Apabila terjadi penyimpangan terhadap proses transaksi yang berhubungan dengan ketiga unsur tersebut, maka langsung dilakukan diskusi terkait pemecahan masalahnya. Berdasarkan hasil evaluasi pada unsur-unsur dalam dimensi aktivitas pengendalian, maka pernyataan-pernyataan per unsur dengan hasil terendah dapat diberikan solusi seperti yang disajikan pada Tabel 10 berikut.

Tabel 10.

Solusi untuk Efektivitas Unsur Dimensi Aktivitas Pengendalian

\begin{tabular}{|c|c|c|c|c|}
\hline No & Unsur & Pernyataan & Skor & Solusi \\
\hline 1. & $\begin{array}{l}\text { Review Kinerja } \\
\text { Departemen }\end{array}$ & $\begin{array}{l}\text { (Pernyataan 1) } \\
\text { Membandingkan kinerja } \\
\text { dengan tolok ukur kinerja } \\
\text { yang ditetapkan. }\end{array}$ & 4,94 & $\begin{array}{l}\text { Pimpinan perlu terlibat dalam } \\
\text { segala kegiatan review serta } \\
\text { kegiatan pengendalian harus } \\
\text { dijalankan, seperti rekonsiliasi } \\
\text { dan ketepatan informasi. }\end{array}$ \\
\hline 2. & Pembinaan SDM & $\begin{array}{l}\text { (Pernyataan 3) } \\
\text { Membuat strategi } \\
\text { perencanaan dan } \\
\text { pembinaan sumber daya } \\
\text { manusia yang mendukung } \\
\text { pencapaian visi dan misi } \\
\text { perusahaan. }\end{array}$ & 4,74 & $\begin{array}{l}\text { Pemahaman bersama atas visi, } \\
\text { misi, tujuan, nilai, dan strategi } \\
\text { yang telah tercermin dalam } \\
\text { rencana strategis, rencana } \\
\text { kerja, dan pedoman panduan } \\
\text { kerja lainnya, serta telah } \\
\text { dikomunikasikan secara jelas } \\
\text { dan konsisten kepada seluruh } \\
\text { pekerja. }\end{array}$ \\
\hline 3. & $\begin{array}{l}\text { Pengendalian } \\
\text { Pengelolaan } \\
\text { Sistem Informasi }\end{array}$ & $\begin{array}{l}\text { (Pernyataan 6) } \\
\text { Melaksanakan } \\
\text { pengendalian aplikasi } \\
\text { yaitu berupa: otorisasi, } \\
\text { kelengkapan, akurasi, } \\
\text { serta kehandalan } \\
\text { pemrosesan dan file data. }\end{array}$ & 4,89 & $\begin{array}{l}\text { Menganalisis area yang perlu } \\
\text { mendapat perhatian lebih dan } \\
\text { lakukan pengawasan secara } \\
\text { kontinu. }\end{array}$ \\
\hline
\end{tabular}




\section{Pengendalian Fisik Aset}

5. Review Indikator dan Ukuran Kinerja

6. Pemisahan Fungsi

7. Otorisasi Transaksi Penting

8. Pencatatan yang Akurat dan Tepat

Waktu atas

Transaksi

9. Pembatasan Akses Sumber Daya dan Pencatatannya

10. Akuntabilitas Sumber Daya dan Pencatatannya

11. Dokumentasi SPI
(Pernyataan 8)

Menetapkan, mengimplementasikan, dan mengkomunikasikan kepada seluruh pekerja rencana pemulihan setelah bencana.

(Pernyataan 12)

Membandingkan secara terus-menerus data pencapaian kinerja dengan sasaran yang ditetapkan dan selisihnya dianalisis lebih lanjut.

(Pernyataan 13)

Pimpinan proyek menjamin seluruh aspek utama transaksi atau kejadian tidak dikendalikan oleh 1 (satu) orang pekerja.

(Pernyataan 14)

Pimpinan proyek menetapkan dan mengkomunikasikan syarat dan ketentuan otorisasi kepada seluruh pekerja.

(Pernyataan 15)

Mengklasifikasi transaksi dan kejadian dengan tepat dan dicatat segera.

(Pernyataan 17)

Pimpinan proyek memberikan akses hanya kepada pegawai yang berwenang dan melakukan review atas pembatasan tersebut secara berkala.

(Pernyataan 18)

Pimpinan proyek menugaskan pegawai yang bertanggung jawab terhadap penyimpanan sumber daya dan pencatatannya serta melakukan review atas penugasan tersebut secara berkala.

(Pernyataan 19)

Pimpinan proyek memiliki, mengelola,
4,83 Menegaskan kebijakan prosedur guna meminimalisir risiko yang mungkin muncul akibat kejadian berdampak besar tak terduga.

5,00 Meningkatkan analisis terhadap perbedaan hasil kinerja dari waktu ke waktu sehingga dapat menentukan tindakan korektif yang tepat.

4,68 Pimpinan dibantu oleh pengawas internal terpercaya melakukan review rutin, sehingga apabila terjadi penyimpangan, tindakan korektif bisa segera diambil.

4,80 Jadikan otorisasi sebagai suatu kondisi dan syarat yang wajib dalam siklus kerja serta otorisasi harus sejalan dengan aturan dan ketentuan yang ditetapkan oleh pimpinan.

5,05 Hindari penundaan pencatatan transaksi terlebih yang sifatnya penting serta buat klasifikasi terkait transaksi tersebut sehingga memudahkan proses kerja.

4,94 Pimpinan dibantu oleh pengawas internal terpercaya melakukan review rutin, sehingga apabila terjadi penyimpangan, tindakan korektif bisa segera diambil.

5,09 Pimpinan dibantu oleh pekerja terpercaya yang kompeten dalam menilai terjadinya penyimpangan, dimana review rutin tetap dijalankan secara intensif.

Meningkatkan proses

identifikasi, penerapan, dan evaluasi atas tujuan dan fungsi 
memelihara, dan secara berkala memutakhirkan dokumentasi yang mencakup seluruh Sistem Pengendalian Internal serta transaksi dan kejadian penting. yang ditetapkan pada tingkat kegiatan yang tercermin dalam kebijakan dan pedoman perusahaan.

Sumber: Pedoman Penyelenggaraan SPIP BPKP, 2009

Dalam rangka mengetahui perbaikan dari unsur dimensi informasi dan komunikasi, maka perlu ditelusuri dari masing-masing pernyataan per unsur seperti yang disajikan pada Tabel 10 berikut.

Tabel 10.

Gambaran Hasil Skor Unsur Dimensi Informasi dan Komunikasi

\begin{tabular}{lll}
\hline Unsur & Rata-rata Jawaban & Keterangan \\
\hline $\begin{array}{l}\text { Informasi } \\
\text { Rata-rata nilai per unsur }\end{array}$ & 5,00 & Sangat Informatif dan \\
& & Komunikatif \\
a) Pemberian informasi & 4,94 & Informatif dan Komunikatif \\
b) Penyelenggaraan & 5,06 & Sangat Informatif dan \\
$\quad$ komunikasi efektif & & Komunikatif \\
Komunikasi & & \\
Rata-rata nilai per unsur & 4,84 & Informatif dan Komunikatif \\
a) Komunikasi efektif & 4,88 & Informatif dan Komunikatif \\
b) Pemanfaatan sarana & 4,80 & Informatif dan Komunikatif \\
\hline
\end{tabular}
Sumber: Data diolah, 2018

Berdasarkan tabel hasil skor penilaian unsur dimensi informasi dan komunikasi di atas, kedua unsur mendapat skor penilaian di bawah nilai maksimum 6, sehingga kedua unsur perlu mendapat perbaikan terutama dari unsur komunikasi sebagai skor penilaian terendah. Berdasarkan hasil wawancara dan observasi di lokasi penelitian, unsur informasi dan komunikasi diwujudkan baik proses kerja dalam gedung divisi maupun di lokasi kerja proyek dengan mengkomunikasikan informasi dalam bentuk apapun secara tepat waktu dan efektif antar pekerja. Proses tersebut telah memanfaatkan berbagai bentuk dan sarana komunikasi yang beberapa telah disediakan oleh perusahaan. Khususnya pengerjaan proyek di lapangan, unsur informasi dan komunikasi ini sangat 
penting dan krusial dan harus melibatkan seluruh pekerja sehingga segala bentuk permasalahan ataupun informasi penting yang dapat memengaruhi pengerjaan proyek dapat segera diketahui dan diselesaikan. Berdasarkan hasil evaluasi pada unsur-unsur dalam dimensi informasi dan komunikasi, maka pernyataanpernyataan per unsur dengan hasil terendah dapat diberikan solusi seperti yang disajikan pada Tabel 12 berikut.

Tabel 12.

Solusi untuk Efektivitas Unsur Dimensi Informasi dan Komunikasi

\begin{tabular}{|c|c|c|c|c|}
\hline No & Unsur & Pernyataan & Skor & Solusi \\
\hline 1. & Informasi & $\begin{array}{l}\text { Pimpinan proyek } \\
\text { mengidentifikasi, mencatat, } \\
\text { dan mengkomunikasikan } \\
\text { informasi dalam bentuk dan } \\
\text { waktu yang tepat. }\end{array}$ & 4,94 & $\begin{array}{l}\text { Pimpinan wajib menerima } \\
\text { seluruh informasi baik internal } \\
\text { maupun eksternal sehingga } \\
\text { informasi dapat didistribusikan } \\
\text { secara tepat waktu kepada pihak } \\
\text { yang tepat. }\end{array}$ \\
\hline 2. & Komunikasi & $\begin{array}{l}\text { Menyediakan dan } \\
\text { memanfaatkan berbagai } \\
\text { bentuk dan sarana } \\
\text { komunikasi. }\end{array}$ & 4,80 & $\begin{array}{l}\text { Pimpinan menunjukkan } \\
\text { dukungan dan komitmennya } \\
\text { dengan menyediakan sarana dan } \\
\text { pendanaan yang memadai } \\
\text { kepada para pekerjanya. }\end{array}$ \\
\hline
\end{tabular}

Sumber: Data diolah, 2018

Dalam rangka mengetahui perbaikan dari unsur dimensi pengawasan, maka perlu ditelusuri dari masing-masing pernyataan per unsur seperti yang disajikan pada Tabel 13 berikut.

Tabel 13.

Gambaran Hasil Skor Unsur Dimensi Pengawasan

\begin{tabular}{lll}
\hline Unsur & Rata-rata Jawaban & Keterangan \\
\hline $\begin{array}{l}\text { Pengawasan Berkelanjutan } \\
\text { a) Pernyataan 1 }\end{array}$ & Efektif \\
$\begin{array}{l}\text { Evaluasi Terpisah } \\
\text { a) Pernyataan 2 }\end{array}$ & Efektif \\
$\begin{array}{c}\text { Tindak Lanjut Rekomendasi Hasil Audit dan Review Lainnya } \\
\text { a) Pernyataan 3 }\end{array}$ & 4,83 & Efektif \\
\hline
\end{tabular}

Sumber: Data diolah, 2018

Berdasarkan tabel hasil skor penilaian unsur dimensi pengawasan di atas, dapat dilihat bahwa unsur tindak lanjut rekomendasi hasil audit dan review lainnya memiliki nilai tertinggi sebesar 4,86 dan unsur dengan nilai terendah yaitu 
Ni Made Win Karoyani dan A.A.N.B. Dwirandra. Evaluasi ...

unsur pengawasan berkelanjutan sebesar 4,80. Seluruh skor penilaian unsur dimensi pengawasan mendapat nilai di bawah nilai maksimum 6, sehingga seluruh unsur perlu mendapat perbaikan terutama dari unsur pengawasan berkelanjutan sebagai skor penilaian terendah. Berdasarkan hasil wawancara dan observasi di lokasi penelitian, unsur pengawasan berkelanjutan dilakukan melalui proses rutin, pembandingan, rekonsiliasi, dan tindakan lain yang terkait dalam pengerjaan proyek pemerintah di lapangan. Pengawasan berkelanjutan ini dilakukan oleh Manajer Operasional sebagai pengawas internal. Dimana pengawas menerima laporan terlebih dahulu dari Pimpinan masing-masing proyek, apabila ditemukan masalah yang cukup serius, maka pengawas langsung terlibat dalam proses di lapangan, namun apabila masalah tersebut masih dapat diselesaikan oleh Pimpinan proyek, maka cukup Pimpinan proyek yang menyelesaikan masalah bersama pekerja di proyek tersebut. Dalam jangka waktu tertentu pengawas internal juga melakukan pengecekan lapangan ke seluruh proyek yang ditangani oleh Divisi Gedung II untuk lebih memastikan hasil dari pengerjaan proyeknya.

Evaluasi terpisah selalu dilakukan dengan membandingkan hasil kerja proyek dan daftar uji mutu/kualitas yang di awal proyek diinformasikan kepada seluruh pekerja proyek. Proses evaluasi ini biasanya dilakukan oleh pengawas internal Divisi Gedung II, namun untuk evaluasi rutin dalam jangka waktu singkat biasanya dilakukan oleh Pimpinan proyek saja. Tindak lanjut hasil evaluasi atau review lainnya yang dilakukan baik oleh pengawas internal maupun pimpinan proyek juga selalu dilakukan, terlebih apabila ditemukan masalah yang memang 
harus segera ditindaklanjuti dan diselesaikan agar tidak mempengaruhi hasil proyek untuk ke depannya. Berdasarkan hasil evaluasi pada unsur-unsur dalam dimensi pengawasan, maka pernyataan-pernyataan per unsur dengan hasil terendah dapat diberikan solusi seperti yang disajikan pada Tabel 14 berikut.

\section{Tabel 14.}

Solusi untuk Hasil Efektivitas Unsur Dimensi Pengawasan

\begin{tabular}{|c|c|c|c|c|}
\hline No & Unsur & Pernyataan & Skor & Solusi \\
\hline 1. & $\begin{array}{l}\text { Pengawasan } \\
\text { Berkelanjutan }\end{array}$ & $\begin{array}{l}\text { Melakukan pengawasan } \\
\text { kegiatan pengelolaan rutin, } \\
\text { supervisi, pembandingan, } \\
\text { rekonsiliasi, dan tindakan lain } \\
\text { yang terkait dalam } \\
\text { pelaksanaan tugas di lapangan. }\end{array}$ & 4,80 & $\begin{array}{l}\text { Pimpinan perlu memiliki } \\
\text { strategi khusus untuk } \\
\text { meyakinkan seluruh } \\
\text { pekerja bahwa rangkaian } \\
\text { kegiatan pengawasan } \\
\text { berkelanjutan merupakan } \\
\text { tindakan yang efektif, } \\
\text { serta rapat rutin terkait hal } \\
\text { tersebut perlu untuk } \\
\text { dilakukan. }\end{array}$ \\
\hline 2. & $\begin{array}{l}\text { Evaluasi } \\
\text { Terpisah }\end{array}$ & $\begin{array}{l}\text { Melakukan evaluasi melalui } \\
\text { penilaian sendiri, review, dan } \\
\text { pengujian efektivitas Sistem } \\
\text { Pengendalian Internal. }\end{array}$ & 4,83 & $\begin{array}{l}\text { Proses evaluasi yang } \\
\text { dilakukan oleh pihak } \\
\text { internal harus bersifat } \\
\text { independen dan reguler } \\
\text { dilaksanakan untuk } \\
\text { membantu pimpinan } \\
\text { proyek mengetahui } \\
\text { masalah lebih awal dan } \\
\text { tindakan koreksi yang } \\
\text { tepat untuk dilakukan. }\end{array}$ \\
\hline 3. & $\begin{array}{l}\text { Tindak Lanjut } \\
\text { Rekomendasi } \\
\text { Hasil Audit dan } \\
\text { Review } \\
\text { Lainnya }\end{array}$ & $\begin{array}{l}\text { Menyelesaikan dan } \\
\text { melaksanakan tindak lanjut } \\
\text { secara segera sesuai dengan } \\
\text { mekanisme penyelesaian } \\
\text { rekomendasi hasil audit dan } \\
\text { review lainnya yang } \\
\text { ditetapkan. }\end{array}$ & 4,86 & $\begin{array}{l}\text { Pimpinan proyek harus } \\
\text { bersikap tegas sebagai } \\
\text { pihak yang berwenang } \\
\text { untuk memberikan } \\
\text { rekomendasi dan } \\
\text { memutuskan tindakan } \\
\text { yang layak terkait dengan } \\
\text { temuan hasil audit atau } \\
\text { proses review lainnya. }\end{array}$ \\
\hline
\end{tabular}

Sumber: Pedoman Penyelenggaraan SPIP BPKP, 2009

Hasil penelitian pada bagian pembahasan menggambarkan bahwa pelaksanaan sistem pengendalian internal sudah berjalan efektif dari masingmasing dimensi maupun dari unsur pada masing-masing dimensi khususnya terkait pengawasan manajamen internal perusahaan untuk proyek pemerintah yang mereka tangani. Sehingga citra perusahaan yang sedang baik tanpa adanya 
isu kasus kegagalan proyek pemerintah tahun 2018 memang dapat dibuktikan dengan berjalannya sistem pengendalian internal yang sudah efektif terkait pengerjaan proyek Pemerintah di bawah pengawasan PT. Pembangunan Perumahan (Persero) Tbk. Divisi Gedung II.

Meskipun telah masuk dalam kategori efektif, namun baik sistem pengendalian internal, dimensi sistem pengendalian internal, serta unsur masingmasing dimensi belum ada yang mencapai nilai maksimum 6, sehingga bagi perusahaan, hasil penelitian terkait evaluasi efektivitas SPI ini dapat dijadikan sebagai salah satu bahan pertimbangan untuk meningkatkan dan melakukan perbaikan dari sistem pengendalian internal, dimensi, serta unsur masing-masing dimensinya. Bagi perusahaan dengan usaha dan proyek sejenis dapat melakukan evaluasi terkait efektivitas sistem pengendalian internal perusahaannya agar isu kegagalan proyek pemerintah dapat dikurangi dan citra perusahaan dapat membaik yang dibuktikan dengan sudah berjalannya sistem pengendalian internal perusahaan yang telah efektif.

\section{SIMPULAN}

Efektivitas sistem pengendalian internal proyek Pemerintah di bawah pengawasan PT. Pembangunan Perumahan (Persero) Tbk. Divisi Gedung II masuk dalam kategori efektif. Efektivitas masing-masing dimensi sistem pengendalian internal pada proyek Pemerintah di bawah pengawasan PT. Pembangunan Perumahan (Persero) Tbk. Divisi Gedung II masuk dalam kategori efektif. Efektivitas unsur masing-masing dimensi sistem pengendalian internal proyek Pemerintah di bawah 
pengawasan PT. Pembangunan Perumahan (Persero) Tbk. Divisi Gedung II masuk dalam kategori efektif dan sangat efektif.

Pelaksanaan sistem pengendalian internal sudah berjalan efektif, namun berdasarkan hasil penilaian skor responden, skor tersebut belum mencapai nilai maksimum 6, jadi perlu untuk ditingkatkan lagi secara keseluruhan. Masingmasing dimensi sistem pengendalian internal juga belum ada satupun dimensi yang memiliki nilai maksimum 6, sehingga perlu untuk ditingkatkan kembali terutama dimensi pengawasan yang memiliki skor efektivitas terendah. Unsur masing-masing dimensi sistem pengendalian internal yaitu dimensi lingkungan pengendalian unsur yang paling perlu mendapat perhatian yaitu struktur organisasi, dimensi penilaian risiko unsur yang perlu ditingkatkan yaitu identifikasi risiko, dimensi aktivitas pengendalian unsur yang paling perlu ditingkatkan yaitu pemisahan fungsi, dimensi informasi dan komunikasi unsur yang perlu diperhatikan yaitu unsur komunikasi, dan dimensi pengawasan unsur yang perlu untuk ditingkatkan yaitu pengawasan berkelanjutan.

Bagi peneliti selanjutnya agar dapat menggunakan sampel yang lebih banyak dan pada jenis perusahaan yang berbeda pula, serta dapat menambah aspek penilaian misalnya dari aspek GCG atau masalah keprilakuan.

\section{REFERENSI}

Badan Pengawasan Keuangan dan Pembangunan Peraturan Nomor: PER1394/K/SU/2011 tentang Pedoman Penyelenggaraan Sistem Pengendalian Intern Pemerintah pada Kedeputian Badan Pengawasan Keuangan dan Pembangunan. Diakses 25 Mei 2018. 
Badan Pengawasan Keuangan dan Pembangunan Peraturan Nomor: PER1326/K/2009 tentang Pedoman Teknis Penyelenggaraan SPIP (26 Buku). Diakses 14 November 2018.

Badara, M., \& Saidin, S. (2013). Impact of the Effective Internal Control System on the Internal Audit Effectiveness at Local Government Level. Journal of Social and Development Sciences, 4(1), 16-23. https://doi.org/10.5923/j.ijfa.20130202.05

Gesare, M. R., Michael, N., \& Odongo, A. J. (2016). Influence of Internal Control Systems on Fraud Risk Management among Commercial Banks in Kisii Town, Kenya. IOSR Journal of Business and Management, 18(4), 23197668. https://doi.org/10.9790/487X-1804032834.

Jayanti, Ni Putu Indah \& Rasmini, Ni Ketut. (2013). Pengaruh Pengendalian Intern, Motivasi, dan Reward Manajemen pada Perilaku Etis Konsultan. EJurnal Akuntansi Universitas Udayana 5(1), 179-195.

Kumuthinidevi, S. (2016). A Study on Effectiveness of the Internal Control System in the Private Banks of Trincomalee. International Journal of Scientific and Research Publications, 6(6), 600-612. Retrieved from http://www.ijsrp.org/research-paper-0616/ijsrp-p5482.pdf.

Lameng, Agung Kresna Y. A. \& Dwirandra, A.A.N.B (2018). Pengaruh Kemampuan, Pengalaman, dan Independensi Auditor pada Efektivitas Pelaksanaan Prosedur Audit Investigatif. E-Jurnal Akuntansi Universitas Udayana 22(1), 187-215.

Mahendra, Made Andiva \& Ramantha, I. W. (2018). Pelatihan Kerja Memoderasi Pengaruh Tingkat Pendidikan dan Pengalaman Kerja pada Efektivitas Pengendlian Internal. Jurnal Ilmiah Akuntansi dan Bisnis 13(1), 65-74.

Peraturan Pemerintah Republik Indonesia Nomor 60 Tahun 2008 tentang Sistem Pengendalian Intern Pemerintah. Diakses 25 Mei 2018.

Ridho, Achmad \& Andono, Fidelis Arastyo. (2013). Evaluasi Efektivitas Sistem Pengendalian Internal dalam Rangka Mengatasi Tindak Kecurangan (Studi Kasus pada PT. Nurimas Taksi Sidoarjo. Jurnal Ilmiah Mahasiswa Universitas Surabaya 2(2), 1-16.

Rivelino \& Soekiman, Anton. (2016). Kajian Pengendalian Mutu Konstruksi pada Pengawasan Pelaksanaan Pembangunan Jaringan Irigasi Studi Kasus: Pembangunan Jaringan Irigasi di Leuwigoong. Jurnal Konstruksia 8(1), 116. 
Samuel, I. K., \& Wagoki, J. (2014). Assessing the Role of Internal Control System Components in Kenyan Public Universities : a Case Study of Jomo Kenyatta University of Agriculture and Technology, 4(3), 17-28.

Simanjuntak, M. R. A. \& Djukardi, A. K. (2013). Peran Sistem Pengawasan Kinerja Konstruksi pada Proyek Apartemen di Jakarta Selatan (Studi Kasus pada Proyek Aparteman The Kencana) (019K). Jurnal Manajemen Konstruksi, 24-26.

Tunji, S. S. (2013). Effective Internal Controls System as Antidote for Distress in the Banking Industry in Nigeria. Journal of Economics and International Business Research, 1(3), 1-15. Retrieved from http://www.projournals.org/JBM/0520131201.pdf

Zamzami, Faiz \& Faiz, Ihda Arifin. (2015). Evaluasi Implementasi Sistem Pengendalian Internal : Studi Kasus pada Sebuah Perguruan Tinggi Negeri. Jurnal Akuntansi Multiparadigma, 6(1), 20-27. https://doi.org/10.18202/jamal.2015.04.6003. 